\title{
A Survey of Meteoric Activity over Spain during the VIII-XV Centuries
}

MARÍA JOSÉ MARTÍNEZ USÓ (corresponding author)

Universidad Politécnica de Valencia, Spain

(mjmartin@mat.upv.es)

Universidad Politécnica de Valencia. Depto. Matemática Aplicada. IUMPA.

Camino de Vera SN. 46022. Valencia. (España).

\author{
FRANCISCO J. MARCO CASTILLO \\ Universidad Jaime I de Castellón, Spain \\ (marco@mat.uji.es)
}

\begin{abstract}
The lack of astronomical observations from Medieval and early Modern Spanish sourcesis a constant in the records of solar eclipses, meteors and other celestial phenomena. This may be partially explained by the absence of a documentary corpus similar to the Monumenta Germaniae Historica, for example, that the scholars may use for conducting a systematic search of such records; the problems increase by the presence of four different vernacular languages in the peninsula: Castilian, Catalan , Basque and Galician, together with some other minority languages; to which Latin and Arabic must be added for historical research purposes.

Currently, scientific literature records few Medieval Spanish astronomical accounts and most of them are contained in wider Arab surveys or they come from the best known annals and chronicles. Our paper intends to fill this gap partially in the issue of meteoritic activity. We present a survey of meteors, bolides and meteor storms observed in Spain in the VIII-XIV centuries. Most of them have not been previously published and come from local or minor sources but, for the sake of completeness, we have included some records already mentioned by other authors.
\end{abstract}

Keywords: Astronomical Sources, History of Astronomy, Medieval Astronomy, Meteors, Meteor Showers.

\section{INTRODUCTION}

Meteoric activity can be studied by analyzing observational records written in historical archives such as annals, chronicles and personal diaries. Unlike eclipses, comets and even meteor showers, individual bolides or falling of meteors are local phenomena, so they are more likely to appear in local sources.

The scarcity of records about meteors is surely due to its brief duration and the previously stated local character, with the exception of meteor showers. In Ancient and Medieval ages, they were usually considered as omens, signs of God or reinforcements of previous facts. However, they do not seem to have been considered as important as comets or eclipses, with some remarkable exceptions.

In general, when we find a description of an astronomical phenomenon in a chronicle, we usually face two problems. In the first place, the dating of the event and, secondly, the identification of its precise nature. The identification of such phenomena is, sometimes, quite difficult. The chronicler is not always a witness and even in this case, he may not clearly specify the nature of the event, due to simplifications or lack of knowledge or even due to errors in the copy of an earlier document. Another problem is the use of same terms for different phenomena, as comets, meteors and 
aurorae. In some cases, the context could provide an additional way to discriminate among them, but this is not always possible. This issue has been considered by Dall'Olmo ${ }^{1}$. In accordance to this author, the most important problem that we have found with dealing with medieval meteoritic records is the vague term sign. This name is widely used in chronicles and annals mostly without more speculations, which makes difficult to assign a sentence as, for example, signum in coelo to a specific event.

The present compilation is a result of a broad research into medieval Spanish astronomical sources and should be regarded as an attempt to supply a list of meteoric happenings for a period of eight centuries in Spain. The compilation of a complete list of such phenomena is a hopeless task, even when working with a reduced set of sources or a limited territory, as it is our case. However, there are some previous attempts to cover this issue for European sources, including the early works of Newton $^{2}$ and the most recent from Dall'Olmo ${ }^{3}$, whose list was mainly based in the Monumenta Germaniae Historica (MGH) and the Rerum Italicarum Scriptores (RIS). For the Arab sources, see the works of Rada and Stephenson ${ }^{4}$ (including the comments of Kidger ${ }^{5}$ ) and Cook $^{6}$. Spanish sources are scarcely represented in these surveys ${ }^{7}$. Analogously, Corean, Japan and Chinese records may be found, for example, in Imoto and Hasegawa ${ }^{8}$.

Regarding to the sources for Spain, there are only two partial collections ${ }^{9}$ and some websites where some of the events are collected ${ }^{10}$, but the entries provided are often incomplete or present wrong dates. In addition, we have the important problem that there is not a documentary corpus similar to MHG for the Iberian Peninsula, even when in España Sagrada (51 volumes, mainly written by Enrique Florez in the XVIIIth century) numerous minor chronicles are collected. A similar contemporary case is the Catalunya Carolingia project ${ }^{11}$ for the Catalan area. Therefore, in many cases, we had to work with local or particular records.

Summing up, the survey that we present in this paper is based on local Spanish sources previously unnoticed in the scientific literature and, in some cases, written in vernacular language. No record previous to the eighth and later than the fifteenth century has been taken into account, with the exception of a dubious record from the VIth century.

A typical meteor record may reveal many data, such as date, time, star and end points, brightness, color and sound. Regretfully, it is very rare to find all these data in the same observation. We have tried to identify each entry with one of the annual meteor shower, whenever this has been possible. In some cases, the register does not provide enough information to attempt identification.

Few of the records that we include are dateless. Once again, in some cases, the context may provide useful data to get further information. Original Arabic documents are not dated according to the Anno Domini (AD), but from the Hijra (AH) and it should also be pointed out a particularity that appears in early Medieval Spanish documents: in several reports the word "Era" appears at the end of the paragraph or next to the year, referring to the Spanish era. In order to translate the date to the Anno Domini, we must subtract 38 years to the year provided. The Spanish era, also known as Hispanic era or Caesar era, refers to the dating system used in 
Hispania from the $3^{\text {rd }}$ to the 14 th century, when the Anno Domini system was adopted. Its first year corresponds to $38 \mathrm{BC}$, probably the date of a new tax imposed by the Roman Republic on the population of Iberia related to the beginning of the Pax Romana in Hispania. The reason why it was so widely used in medieval Spain is not known ${ }^{12}$.

Along the paper, all dates are given in the Julian calendar, unless stated otherwise. We make the distinction between "Meteor Reports" and "Dubious Reports", being the first those that we consider documented real meteors, bolides or meteor storms. "Dubious Reports" refer to those that could be meteor phenomena, but we think that other possibilities are far more likely. A list of the meteor records may be found in table 2 .

Finally, we should make some considerations regarding the language in which these documentary sources were written. We have worked with more than a hundred documents, including original manuscripts and works transcribed and published by other authors. Some of the sources have not been published in English or Spanish, and they remain in Latin or in any of the older versions of other languages spoken in Spain. In this case, we have included the original paragraph. For the Arabic sources we have always used a translated version of the original. All the translations have been carried out by the authors with the occasional help of the translating services of the Jaime I University of Castellón. Parenthesis "(...)"and brackets are used respectively to indicate omitted text and explanations not contained in the original document.

The final aim of this work, out of the scope of this paper, is to make a further and enlarged survey of European sources, in order to obtain reliable data about the origin and evolution of meteor storms along the years, following the methodology by SangHyeon $^{13}$. This work has already been done for Asian sources but, as far as we known, no one has covered this issue in the European (or worldwide) case.

\section{METEORS REPORTS}

(1) Cordoba $\left(\lambda=4^{\circ} 46^{\prime} \mathrm{W}, \varphi=37^{\circ} 53^{\prime} \mathrm{N}\right.$ Andalusia, Southern Spain), AD750 April 5

El domingo cinco de abril de la era 788, año sexto del reinado de Constantino, a las 7, 8 y 9 de la mañana, los habitantes de Córdoba que estaban mirando vieron tres estrellas que se movían de una forma extraña y como si hubiesen perdido brillo precedidas por una especie de hoz color de fuego o esmeralda. Después de su aparición, unos ángeles, enviados por orden divina, causaron estragos entre todos los habitantes de España con un hambre insoportable.

On Sunday 5 April era 788, in the sixth year of the reign of Constantine, at 7, 8 and 9 in the morning, the inhabitants of Cordoba who were watching saw three stars moving in a strange way as if they had lost bright preceded by a 
fire or emerald coloured sickle. After their appearance, angels, sent by divine command, have wreaked havoc among the people of Spain with an unbearable hunger

This text belongs to the so called Crónica Mozárabe de $754^{14}$ that was also published and commented in the EPS SAG 8 (p. 322), under the name of Cronicon del Pacense. It is a medieval chronicle written in the eighth century by a bishop of a Lusitanian diocese called Isidore, with the aim of being a continuation of the history of the Goths of Isidore of Seville (around 556-636); it covers a period of more than 300 years from AD610, the first year of Emperor Heraclius, until AD754.

The word era before the year bring us to the year AD750. Emperor Constantine V (718-775) reigned between AD741 and AD775, so the data is not consistent with the sixth year of his reign. This may be due to the doubts about the year in which Constantine became king, but these errors in the imperial dates are constant throughout the document. The Chronici rerum memorabilium Hispaniae of Johannis Vasaeus $^{15}$ provides a virtually identical definition of the event, but for the year AD747. We have chosen the first report taking into account the day of the week, because both reports assert that $5^{\text {th }}$ April was Sunday, but in AD747 this day was Wednesday.

Vasaeus ${ }^{16}$ refers again to this event in the entry of year AD753, but in this case he identifies his original source as Rodericus Toletanus, namely Rodrigo Jiménez de Rada, author of De rebus Hispanicis lib[ri] 9 et Historia Romanorum, Osthrogothorum, Hunnorum, Alanorum, Siling[orum] Arabum, that was translated in Crónica De España Por El Arzobispo De Toledo Don Rodrigo Jiménez De Rada, Traducida Al Castellano Y Continuada Por Don Gonzalo De La Hinojosa ${ }^{17}$. From this source is the following extract:

E en este segundo año del rey don Fruela, vieron los moros de Córdoua tres soles muy claros e muy lucientes, e yvan uno en pos de otro, echando de ser muy grandes rayos como fuego ardiente. E esto duró desde ora de tercia fasta hora de nona.

And in this second year of the reign of King Fruela the Moors of Cordoba saw three very clear and shiny suns and they were [moving] one after another leaving behind large rays as burning fire. And this lasted from the third hour until the ninth hour.

The second year of King Fruela of Asturias (722-768) corresponds to era 792 that is AD754, but no more precision about the date is given. So uncertainty remains if we are dealing with two independent events or only one but narrated twice.

Our first guess is to identify this meteor as a Lyrid: Sunday 5 April corresponds to 9 April in Gregorian calendar. Lyrids is a meteor storm, caused by the comet C/1861G1 (Thatcher), which currently appears from 16th to 25th April. That is a bit too early to be Lyrids. On the other hand, they could be simple sporadic meteors taking into 
account that February, March, and April evenings have the notable feature that an unusual number of sporadic fireballs come in this interval.

(2) Spain, AH 224, AD 839 April-May

In djomāda II there was a meteor storm in all Spain and a lot of stars were seen flying from South to North and from East to West.

From Annales du Maghreb et de l'Espagne ${ }^{18}$. The Arab month jumādà at-tāniya began on April 20 and ended on May 18 so the approximate date of this storm can be quite well established. Cook ${ }^{19}$ and Rada and Stephenson ${ }^{20}$ include this register, but in the case of Rada and Stephenson, there is a mistake in the year (AD838). There is the possibility that this same storm was observed also in China, on AD839 May $4^{21}$ and it is surely related to the account narrated by Dall'Olmo ${ }^{22}$ for AD839 May 8.

This storm could correspond to the Lyrids, at the end of its period, but more likely they belong to the Eta Aquariids which is also the opinion of Jennisken ${ }^{23}$. Astapovic and Terenteva ${ }^{24}$ suggest a low activity of this storm in the $8^{\text {th }}-11^{\text {th }}$ century, but H.A. Newton ${ }^{25}$ proposed a maximum for this storm for AD839.

(3) Andalusia (presumably, Cordoba), AH289, AD902 October 28

In this year (...) there was a considerable rain of stars on the $22^{\text {nd }}$ dhoû'l-k'a'da (sic.), so that the year was called "the year of the stars"

From Annales du Maghreb et de l'Espagne ${ }^{26}$. Newton ${ }^{27}$ discuses largely this meteor storm, that is also listed in Rada and Stephenson ${ }^{28}$, including a lot of records from different days and observational sites. Newton states this is a Leonids observation, in agreement with Jenniskens ${ }^{29}$. Let us remember that the Julian date of the maximum of the Leonids meteor storm has progressed by a month, from October 13 in AD902 to November 13 in $\mathrm{AD} 1833^{30}$. Leonids are known to have provided a maximum in AD902, following its 33.25 years of periodicity.

(4) Andalusia (presumably, Cordoba), AH300, AD 912/13

Stars were shooting from the fall of darkness until the end of the night

This register has been taken from the survey given by Rada and Stephenson ${ }^{31}$, who cite the anonymous Kitāb al- 'Uyūn (loosely translated as The Book of Curiosities of the Sciences and Marvels for the Eyes ${ }^{32}$ ). No identification can be attempted due to the lack of data.

(5) San Millán de la Cogolla $\left(\lambda=2^{\circ} 51^{\prime} \mathrm{W}, \varphi=42^{\circ} 19^{\prime} \mathrm{N}\right.$, La Rioja, Northern Spain) AD 934 October 15

A surprising record is found de Offerendis Beati Emiliani (ESP SAG, 50) p.390, originally written in Latin:

Nam in istis fere temporibus, talia in terra apparuerunt signa, quod furor Domini venturus credebatur in ea. In era noningentesima septuagesima secunda, quarto 
dezimo Kalendas augusti, lumen solis die sexta feria amittens lucendi virtutem obscuraum constitit a bora secunda in terciam, quarta feria ydus octubris, coloris eiusdem solis multi cognoverunt effectum pallidum. Signa magna facta sunt in cello (...) porta flamea aperta est in cello, et ibant stele et comovebant se huc atque illuc (...) noctis media usque mane.

Because in these days signs appeared on earth that showed the wrath of the Lord was near. In era 972, 14 Kalendas August, Friday, the light of the Sun darkened from hora secunda to hora tertia, on Wednesday idus October the color of this same sun was grey. There were great signals on the sky, (...) a fire door opened in the sky and the stars were going from here to there (...) and it lasted from midnight to the morning.

Era 972 corresponds to AD934. 14 kalendas August was Saturday 19 July. This day there was no eclipse, surely the author refers to AD939 July 19 that was indeed Friday and in S. Millan de la Cogolla there was a large partial eclipse with a magnitude of 0.97 .

On the other way, idus October corresponds to Wednesday AD934 October 15, when errant stars were seen from midnight to the morning. The Anales Casinates (MGH SS 3 ) also reports signis in the stars for this date and we also found two accounts in China for AD934 October 13 and $14^{33}$ and Turkey ${ }^{34}$, so it seems that all these references point to the same star storm. Kidger ${ }^{35}$ states that Leonids are the most probable identification though the alleged year for the maximum is AD935.

More information is provided in the Historia general de España ${ }^{36}$ :

El alfaquí mayor de los moros, que es como obispo entre ellos, vino en poder del conde. Con esto, la provincia y la gente pareció alentarse del grande espanto causado del aparato que los contrarios hicieron para aquella guerra, además de muchas señales que en el cielo se vieron y muchos prodigios; porque en el mismo año que fue la pelea, es a saber, el de 934 (otros a este número añaden cuatro años), siendo reyes don Ramiro en León, y don Garci Sánchez en Pamplona, hubo un eclipse del sol o los 19 de julio (más quisiera a los 18, porque dicen fue viernes) por espacio de una hora entera a las dos de la tarde, tan grande y cerrado, que se mudó el día en muy espesas tinieblas. Segunda vez a 15 de octubre, que fue miércoles, la luz del sol se volvió amarilla, en el cielo apareció una abertura, cometas de extraordinaria forma, que caían a la parte de mediodía; las tierras fueron abrasadas por oculta fuerza de las estrellas, sin otras cosas que daban a entender la ira de Dios (...)

Otros dicen que en el mismo día de la batalla se eclipsó el sol a 6 de agosto, día de los santos Justo y Pastor, que fue lunes.

Estas señales tenían a todos muy congojados; pero ganada la victoria, se trocó el temor en alegría y se entendió que no amenazaban a los fieles, sino a sus enemigos. 
The great alfaqui of the Moors, who is like a bishop among them, fell into the hands of the Count. With this, the province and the people seemed to encourage against the great fright caused by the preparations that the opponents have made for the war, in addition, there were many signs in the sky and many wonders; because in the same year that the fight, that is, 934 (some add to this number four years), being kings Don Ramiro in Leon, and Don Garci Sanchez in Pamplona, there was a sun eclipse on 19 July (most likely on 18, because they say it was Friday) for about an hour at two in the afternoon, so large and closed, that the light of day changed into a very thick darkness. Secondly on 15 October, that was Wednesday, the light of the sun turned yellow, in the sky appeared an opening, comets dramatically fell to the part of midday; the land was scorched by hidden force of the stars, things that suggested no other that the wrath of God and his anger (...)

Others say that in the same day of battle, the day of the saints Justo and Pastor, which was Monday, 6 August, the sun eclipsed.

These signals were all very distressing; but once the victory was obtained, fear changed into joy and it was understood that the threat was not for the faithful ones, but for the enemies.

Ramiro II (900-951) was King of Leon from 931, García Sánchez I (919-970) was king of Pamplona from 925. In May 934 'Abd-al-Rahmân III (989/91-961) led a military expedition against Ramiro II that lasted until the Battle of Simancas (939), where kings Ramino and García defeated the caliphate army.

As we see, there are plenty of astronomical references, but still remains the confusion of dates that we have previously mentioned. Again, it seems that the author confuses the Roman division of daylight in twelve hours and the contemporary way of measuring time. He says the eclipse occurred at two in the afternoon, while the original manuscript speaks of "hora secunda in tertiam". The maximum of the eclipse occurred in the Peninsula about 7:30 in the morning that is, indeed, at the Roman "hora secunda" rather than at two.

Regarding to the alleged eclipse of Monday August 6 this is not right because AD934 August 6 was Wednesday and the same day in AD939 was Tuesday. And there is not any eclipse of sun visible in Spain near this time (in an interval spanning 10 years before and after). There is not any eclipse of moon, either.

Both texts narrate roughly the same facts. On the other way, in the Al-Muqtabis ${ }^{37}$ a shower of stars that coincides with this date:

At the beginning of Dhu al-Qu'da, groups of stars in mid-sky were scattering from east to west and from west to east. They were fascinating to the observers

The beginning of the month that year coincided with October 13, so it's very possible that we have two Spanish sources for the same event. 
At the end of this year which was the 12th of Dhu al-Qu'da, stars were shooting extensively in the atmosphere. Most of them were directed from mid-sky to the western horizon. Among them, a great star appeared from the east like a column. It competed with the moon and was nearly splitting it as seen by the observer's eye.

From the Al-Muqtabis, it seems the description of a storm and a large meteor that crossed the Moon. This report is compiled by Rada and Stephenson ${ }^{38}$. Kidger ${ }^{39}$ identifies this storm with the Leonids, in coincidence with the year of the expected maximum activity, following the Leonids period of 33.25 years.

(7) Zamora, Carrión, Castrojériz, Burgos, Briviesca, Sto Domingo de la Calzada, Pancorbo, Buradón, AD939 June 1

Era DCCCCLXXXVII. Kalend. Iunii, die Sabbati hora nona flamma exivit de mari, \& incendit plurimas urbes, \& Villas, \& homines, \& bestias, \& in ipso mari pinnas incendit: \& in Zamora unum barrium, \& in Carrion, \& in Castroxeriz, \& in Burgos. C. casas, \& in Birbiesca , \& in Calzada, \& in Pontecorvo, \& in Buradon, \& alias plurimas Villas combusit.

Era DCCCCLXXXVII, Kalendas Iunii, Saturday, at the ninth hour, a flame went out the sea and burned many villages and cities and men and beasts and in this sea there were wings of fire: and burnt in Zamora a neighborhood, and in Carrion and Castro Xeriz, and in Burgos [burnt] a hundred of houses and in Briviesca, and in Calzada and in Pancorvo and in Belorado and in many other villas.

In the previous paragraph some villages and cities appear with their medieval name, we include in table 1 the list of these places with their ancient and their current name, together with their coordinates to make them easier to find.

\begin{tabular}{|c|c|c|}
\hline Medieval Name & Modern Name & Coordinates \\
\hline Zamora & Zamora & $\lambda=5^{\circ} 45^{\prime} \mathrm{W}, \varphi=41^{\circ} 30^{\prime} \mathrm{N}$ \\
\hline Carrion & Carrión de los Condes & $\lambda=4^{\circ} 36^{\prime} \mathrm{W}, \varphi=42^{\circ} 20^{\prime} \mathrm{N}$ \\
\hline Castroxeriz & Castrojériz & $\lambda=4^{\circ} 08^{\prime} \mathrm{W}, \varphi=42^{\circ} 16^{\prime} \mathrm{N}$ \\
\hline Burgos & Burgos & $\lambda=3^{\circ} 42^{\prime} \mathrm{W}, \varphi=42^{\circ} 20^{\prime} \mathrm{N}$ \\
\hline Birbiesca & Briviesca & $\lambda=3^{\circ} 19^{\prime} \mathrm{W}, \varphi=42^{\circ} 33^{\prime} \mathrm{N}$ \\
\hline Calzada & Sto Domingo de la Calzada & $\lambda=2^{\circ} 57^{\prime} \mathrm{W}, \varphi=42^{\circ} 26^{\prime} \mathrm{N}$ \\
\hline Pontecorvo & Pancorbo & $\lambda=3^{\circ} 06^{\prime} \mathrm{W}, \varphi=42^{\circ} 38^{\prime} \mathrm{N}$ \\
\hline Burandon & Buradón & $\lambda=2^{\circ} 50^{\prime} \mathrm{W}, \varphi=42^{\circ} 38^{\prime} \mathrm{N}$ \\
\hline
\end{tabular}

Table 1: List of Medieval and modern name together with their geographical coordinates for the places mentioned in the document for event (7)

This is a beautiful record compiled twice in the Annales Compostelanos (ESP SAG, 23, p. 318) and the Chronicon Burgense (ESP SAG, 23 p. 308) of a bolide that must have been spectacular. It was visible at three in the afternoon on Saturday AD939 June 1. The path is clearly drawn on the map in Figure 1. The author states that it came from the sea, so an observer would have seen it coming from the $\mathrm{W}$ to the NE. 
The list of sites and damages suggest that the meteor exploded and left fragments along its path.

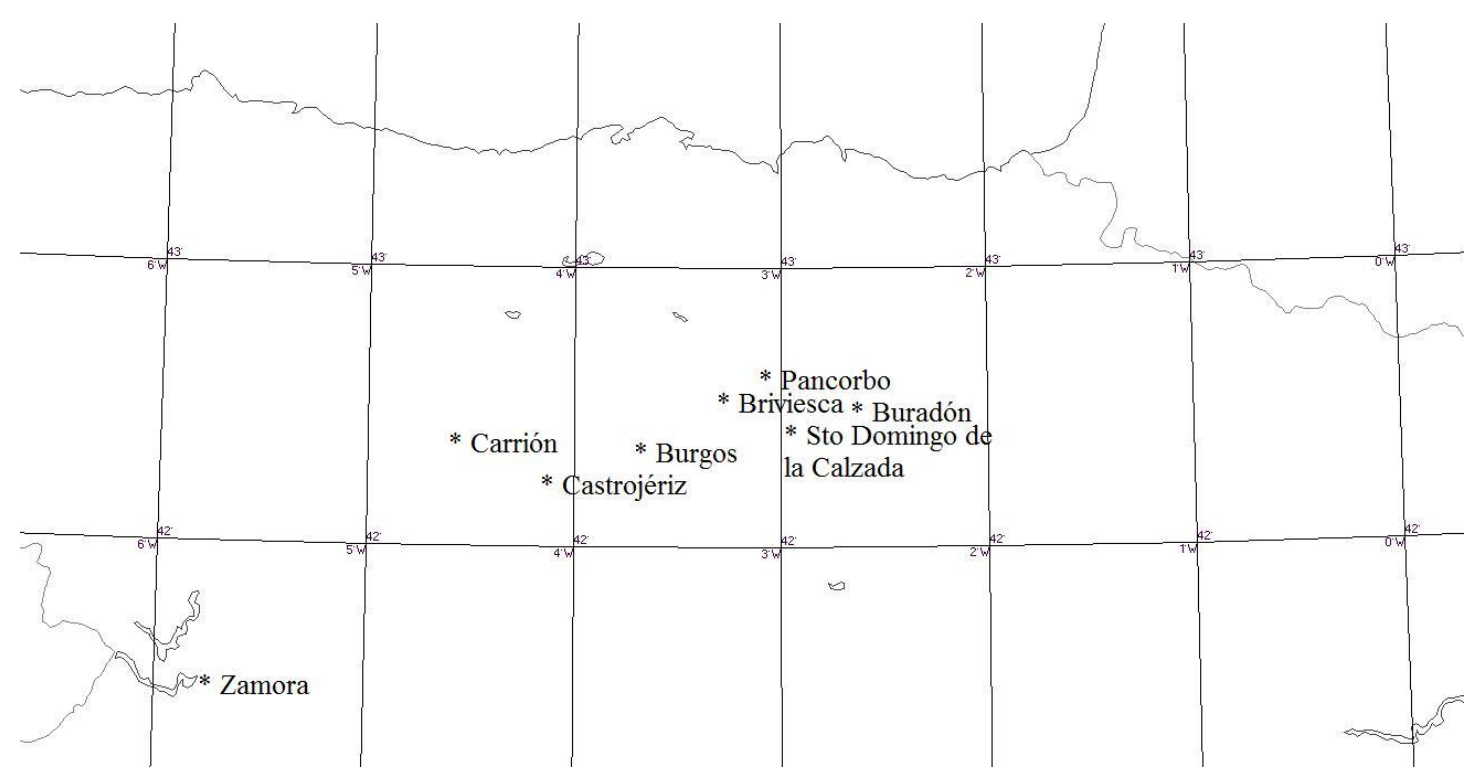

Picture 1: Trajectory of AD939 June 1 bolide. (Using Chris Marriott's SkyMap Pro V11, http:// http://www.skymap.com/ )

(8) Cordoba AH362, AD973 June 25

On the night of Wednesday, 21 Ramadan in the third hour of it, a star with a huge mass and very strong light rose from the South and continued on to the direction of the north. It lit up the entire horizon and the measurement of its light was above that of dry lighting.

This reference belongs to Anales Palatinos del califa de Córdoba Al-Hakam II ${ }^{40}$, which is a translation of part of Ibn Hayyan's Al-Muqtabis . Cook ${ }^{41}$ quotes the same register but assigns to it a wrong date (26 June). In fact, the correct date is Wednesday 25. Ibn Hayyān was not contemporary of this event; he takes the data from 'İsà ibn Aḥmad al-Rāzī, who was contemporary.

(9) Cordoba, end of X- beginning of the XI century

Sed narrauit Auicena lapis magnus cecidit in Corduba, igneus in die sereno, feu claro, et ipse vidir illum alpidem, et ahuit odorem sulphuris et quasi nam ammoniaci.

But Avicena tells that a big stone fell in Corduba, in a clear day and he himself saw the stone, it smelled as sulphide as it was of the nature of the ammonic

This is a report from Ibn Rushd ${ }^{42}$, known as Averroes (1126-1198), in his commentary to Aristotle's Meteorology. Martín Escorza ${ }^{43}$ assumes that the meteor 
fell in the middle of the XIIth century, but the report clearly states that it was Avicena (Ibn Sînâ, 970-1037) who saw the stone, so the exact date of the fall remains unknown but the meteor should be ascribed to the end of X-beginning of the XIth century.

(10) Tortosa $\left(\lambda=0^{\circ} 31^{\prime} \mathrm{E}, \varphi=40^{\circ} 48^{\prime} \mathrm{N}\right.$, Catalonia, Eastern Spain), AD1189 February 24

Era $M^{a} C C^{a} X X V I I$, anno $M^{o} C L X X X I X$, VI kalendas marcii. Ignis de celo visus est per multa loca.

Era 1227, year 1189, February 24. Fire of the sky was seen in several sites.

From the Annals De Tortosa II in Cingolani ${ }^{44}$. We have not found references in other annals. A possibility would be the so called eta virginis meteor shower that peaked at that time (about 3 March).

(11) Serrateix $\left(\lambda=1^{\circ} 47^{\prime} \mathrm{E}, \varphi=41^{\circ} 57^{\prime} \mathrm{N}\right.$, Northern Catalonia), AD1247 January 7

Anno Domini M CC XL VII visus est ignis radius magnus in aere recte super ecclesiam Sancti Petri Serretexi, et dum videretur radius iam vicinus terre divisus fuit in duas partes et statim edanuir ab oculis. Et hoc fuit post vespertinos (...) celo sine nube solisque splendore (...)

AD 1247. It was seen a big lighting in the air right over the church of Sancti Petri Serrateix, and then the lighting was divided into two parts when [it was] near the earth and soon disappeared from view. And this happened after 6 in the afternoon (...) the sky was without clouds and the sun was shinning (...)

Description of a bolide reported in the Necrologic de Serrateix ${ }^{45}$, it was seen after visperas (about 6pm) it broke in two and vanished. This meteor could belong to the daytime Arietids.

(12) Castrillo del Val, ( $\lambda=3^{\circ} 36^{\prime} \mathrm{W}, \varphi=42^{\circ} 18^{\prime} \mathrm{N}$, near Burgos, Northern Spain) AD1254 October (around 18th)

Era de MCCXCII. años en dia de Sant Lucas entró en Burgos Don Adoart, e prisó por muger à la hermana del Rey D. Alfonso (...). Vino un fuego del Cielo, è cayó antel Rey en la Glera de Burgos, e fizo gran sueno

Era MCCXCII years on St. Luke day D. Adoart came to Burgos and married the sister of King Alfonso (...). A fire from the heaven came and fell in front of the king in the Glera ${ }^{46}$ of Burgos and it made a big noise 
Era 1292 corresponds to AD1292. Account took from the Chronicón de Cardeña, in ESP SAG, 23, p. 373 from the Monastery of San Pedro de Cardeña, sited in Castrillo del Val, near Burgos. The wedding between Leonor of Castile, half-sister of Alfonso $\mathrm{X}$, with the Prince of Wales (future Edward I of England), was held in Las Huelgas Monastery, in Burgos (18th October) The remark about the sound may correspond to a bolide that burst in the sky.

(13) Aragón, AD 1300

A handwritten chronicle preserved in the National Museum of Pest (Hungary) concerns the fall of large meteoric stones in Aragon, this record was collected by Paluzie $^{47}$ without providing further details.

In another document Jimeno ${ }^{48}$ states that the above text is taken exactly from "Mr. Stanislas Munier in his "Météorites de la Encyclopédie chimique publiée sous la direction de M. Frémy, 1884"

Despite our efforts, we have been unable to locate the original document from the source mentioned herein.

(14) Catalonia, AD1348 December 18

Die Jovis ante Nativitatem Domini Nostri Jesu Christi ignis apparuit de Coelo, tenens ab Oriente ufque Occidentem. In partibus Kataloniae tres lapides maximi ceciderunt de Coelo, quorum quilibet erat maximi ponderis, \& miserunt unum Domino Regi super quodam mulo.

On Thursday before the birth of Our Lord Jesu Christ, fire of sky appeared from East to West. In Catalonia, three big stones fell from the sky and each one of them was very heavy and they sent one of them to the King upon a mule.

Record obtained from the Chronicon Estense (SIR, 15) p. 448. Thursday before Christmas was December 18. The author seems to relate the three stones fallen in Catalonia with the previous star shower. At the time, the king of Aragon was Pedro IV, who left a chronicle written by himself (La Crónica de Pere $I V^{49}$ ) in which he does not mention this event. The time was difficult for the king, who was in the siege of the Kingdom of Mallorca. Maybe such a minor event did not find place in his chronicle.

Dall'Olmo ${ }^{50}$ provides a partial report of this account.

(15) Antequera $\left(\lambda=4^{\circ} 33^{\prime} \mathrm{W}, \varphi=37^{\circ} 01^{\prime} \mathrm{N}\right.$, Andalusia), AD1410 September 2

Estando el Infante sobre Antequera en dos dias del mes de setiembre (...) Y en este dia parecio caer una gran llama del cielo sobre la villa de Antequera.

Being the Infant in Antequera the second of September (...) And that day a big flame seemed to fall from the heaven on the villa of Antequera. 
This report belongs to the Crónica Del Rey D. Juan $I^{51}$. The text does not provide enough information to attempt identification, but it could have been an Alpha Aurigid.

(16) Ciudad Rodrigo $\left(\lambda=6^{\circ} 31^{\prime} \mathrm{W}, \varphi=40^{\circ} 35^{\prime} \mathrm{N}\right.$, Castile and Leon, Western Spain), AD1433 January 5

Estando el Rey en Cibdad-Rodrígo acordó de mandar llamar los Procuradores, los quales mandó que viniesen á la villa de Madrid, y él se partió de CibdadRodrigo en comienzo del año de mil y quatrocientos é treinta y tres años, Lunes cinco dias de Enero, é caminando viéron todos una gran llama que iba corriendo por el cielo, é duró gran rato, é dende á poco dió un tronido tan grande, que se oyó á siete ó ocho leguas dende.

Being the King in Ciudad Rodrigo, he decided to call the Procuradores ${ }^{52}$, whom he ordered to come to the villa of Madrid, and he left Ciudad Rodrigo at the beginning of the year 1433 Monday the $5^{\text {th }}$ of January, and (while they were) walking they all saw a great flame that was running across the sky and lasted long time, and soon it was heard such a big thunder that was heard seven or eight leagues around

Again, a record obtained from the Crónica De D. Juan II ${ }^{53}$. It seems another case of a diurnal bolide, maybe a daytime Arietids. We find also this same event in the Centón epistolario $^{54}$ including a reasoning about the nature of the event.

Caminando miercoles á cinco deste mes de Enero, vimos de repente andar pegada al cielo de una parte para otra una gran flama de fuego amarillo que dentro tenia como raíz negra é los cabos de toda ella eran mas blanquecidos que en la mitad, é despidióse con un gran tronido (...) Ovo sobre esto grandes disputaciones (...) E l Dean de Burgos diz que cree ser materia de la mas primera región, viscosa é condensa, que el sol la encendió é su peso no la dexó desfacerse así luego,é la natura del fuego la trahia de acá para allá mientra que se gastó lo viscoso,é su fin fué el tronido. Yo soy de su opinión; ca no pudo ser de la natura de las cometas que Aristotil llama . . . . porque no sería movible en tanta manera, ni en ninguna, ni se finiría con tronido.

Walking on Wednesday 5th of this month of January, we suddenly saw in the sky, crossing the sky, a great yellow flame, that had inside [something] as a black root, and the tips of all of it were whiter than in the middle, and it disappeared with a loud thunder, ( ... ) there were big disputes about this [event] ( ... ) the Dean of Burgos thinks [that] it should belong to the first region, [that it was] viscous and condensed so the Sun burnt it, and its weight did not allow it to vanish, and the nature of fire brought it crack and forth while the viscosity lasted, and its end was the thunder. I agree with him, as it could not be what Aristotle called comets, because it would not move so much, nor would be extinguished with a thunder. The enemies of the Constable said that the fire was himself, who would burn Castile, and his end would be signaled with a thunder. ( ... ) 
The same event is also commented in Historia General De España $a^{55}$. The author explains that the signs of heaven frightened everyone because of the war against the infants of Aragon and states that the final thunder was heard 30 miles away.

(17) Bayonne ( $\lambda=1^{\circ} 29^{\prime} E, \varphi=43^{\circ} 30^{\prime} N$, South-Western France), AD1451 August 22

(...) y la ultima de las plazas conquistadas Bayona, que se rindió à 21 de Agosto del año de 1451 y el dia siguiente se vio por espacio de media hora sobré esta Ciudad una Cruz, blanca en el Ayre, aprobando el Cielo con esta milagrosa señal la victoria

(...) and the last of the places conquered [was] Bayonne, which surrendered on August 21, 1451 and the following day a white cross in the air was seen for half an hour above this city, approving the sky with this miraculous sign the victory (...)

From the Annales Del Reyno De Navarra ${ }^{56}$. This is, maybe, the description of a late Perseid. Currently, Bayonne is not a Spanish city, but we include this record because, at the epoch, Bayonne belonged to the Reign of Navarre.

(18) Castile, AD 1459

Hubo en un mismo tiempo muchas señales que pronosticaban, como se entendía, los males que por estas causas amenazaban. Éstas fueron una grande llama que se vio en el cielo, que dividiéndose en dos partes, la una discurrió hacia levante y se deshizo, la otra duró por un espacio. Item, en el distrito de Burgos y de Valladolid cayeron piedras muy grandes, que hicieron grande estrago en los ganados.

There were many signs that predicted, as it was understood, the evils that threaten this cause. These were a great flame that was seen in the sky, which was divided into two parts, one was running eastward and vanished, the other lasted for a time. Item, in the district of Burgos and Valladolid fell very large stones, which made havoc among the cattle.

Record of a meteorite that broke in two parts obtained from the Historia General De Españ $a^{57}$. The falling stones in Burgos and Valladolid are likely to be hail. The text has been extracted from a longer paragraph that provides a context according to which this event happened around the time of the council of Mantua (May 1459) and in Castile, no more information can be obtained about the place. 
Dicmenge a XXVIII. Aquest die, a migjorne e ja alguns jorns abans e après diverses hores, per molts fonch vista una molt gran e groça stela ab una gran coha de fonch qui menava gran fum detràs si, exint de les parts de ponent e anant ver lo levant, e per semblant se diu l'an vista en Aragó e en València, de què s'és seguit que mots stròlechs hand it que dins aquest any morrà algun ran prince $e$ seran gran guerres o morts; Déu per sa misericòrdia nos do ço que sab que havem master.

Sunday the 28th. This day, at midday and already some days before and after at different times, a lot of people saw a big star with a large tail of fire that casted much smoke behind it, from the parts of Ponent $[W]$ and going to Llevant $[E]$. And it seems to have been seen in Aragon and Valencia, from this follows that many astrologers have said that this year will die a great prince and there will be many great wars or deaths. May God, in His mercy give us what He knows we need.

The apparition of this star (see figure 2) is recorded similarly in two sources: the Dietaris of the Generalitat de Catalunya ${ }^{58}$, from where the presented fragment comes, and the Llibre de Jornades ${ }^{59}$. Together with records (20) and (21) they have previously been commented by Martínez and Marco ${ }^{60}$. This event was preceded by an earthquake the $1^{\text {st }}$ August and intense storms in September that caused injuries and several material damages, so it is not a surprise that it was seen as a bad omen. These are the years before the Catalan civil war (1462-1272) and the situation in the city of Barcelona was very unstable. That is why the author claims God for "He knows we need".

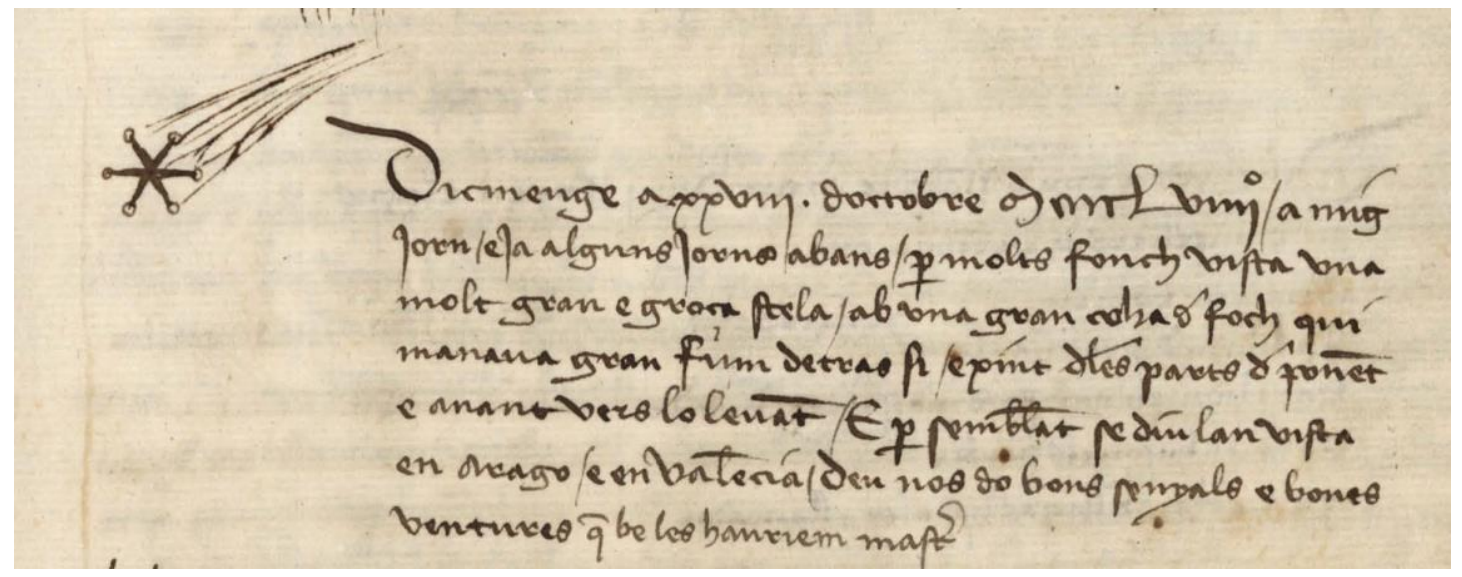

Figure 2: Picture of the meteor in f.61r, in the Llibre de les jornades.

At first sight, the text seems to describe a very bright comet, because it could be seen at midday, and "and already some days before and after" but the only recorded comet for these years was $\mathrm{C} / 1458$, which was not visible on this date ${ }^{61}$. This fact and the paragraph "with a large tail of fire that casted much smoke behind it, from the parts of Ponent and going to Llevant. And it seems to have been seen in Aragon and Valencia" 
seems to fit the description of a meteor. In fact, it is possible that the author refers to an especially brilliant meteor among much others, which would explain the comment that the star was also seen "some days before and after". The date of this entry could suggest that it was a meteor from the Orionids meteor shower, but it was seen at midday and "from the West to the East". At this time it was Leo the constellation that was in the West, so the meteor is likely a Leonid. The radiant of this shower was over the horizon from approximately 0 a.m. to 15 p.m. This interval could correspond to the "different times" of sighting reports.

\section{(20) Barcelona, AD 1464 October 10}

Dimecres, a X. Aquest die, en la nit se viu un gran senyal de foch en lo cel, ten gros com un gran payller, e llançà molta claredat, e fonch entre VI e VII hores, ans de mihanit; Déu, per sa mercè, vulla que de aquest senyal e de tots alters succeesque tot bé e repòs en lo principat de Cathalunya.

Wednesday, the 10th. On this day, in the night, a big sign of fire was seen in the sky. [It was] as big as a big pine tree, and casted much brightness, and [it was seen] between 6 and 7 hours, before midnight; May God, in His mercy, want that this sign and all others bring successful events and peace to the principality of Catalonia.

Record obtained from the Dietari General de Catalunya ${ }^{62}$. At the beginning of the year 1464 and in the context of the civil war, Pedro IV $^{63}$ had been enthroned. In this case, the shooting star was not seen as a bad omen, but the writer prefers to see it as a sign of hope in the civil war against Juan II of Aragon (1398-1479).

This record refers to a meteor seen from Barcelona. It was seen between 6 and 7 hours. In this epoch of the year, the sun sets at about $18 \mathrm{~h} 15 \mathrm{~m}$ and the astronomical twilight ends at about $19 \mathrm{~h} 50 \mathrm{~m}$ so it was not total darkness and the meteor should have been a really shining one. In accordance with the date, this meteor could have belonged to the Draconids.

\section{(21) Barcelona, AD1471 December 18}

Dimecres, a XVIII. Sancta Maria de Sperança. Aquest die, en la matinada, quasi a punta de jorn, féu terratrèmol, e en la nit après següent se viu al cel una ran stela ab raigs, lensant gran claror en forma no acustumada; Déu nos do bons senyals e bona venura, per sa mercè.

Wednesday, the $18^{\text {th }}$ St. María de Sperança. Today, during the sunrise, almost beginning the day, there was an earthquake and in the night after it was seen in the sky a large star with long rays, casting brightness in an unusual way. May God give us good signs and good fortune, for His grace. 
From the Dietari General de Catalunya ${ }^{64}$. At first, we thought that this could have been the first detection of the comet of AD1471, but the paragraph seems to refer to a sudden event, so we finally decided that this is the description of a meteor, maybe related to the Gemidids.

The author seems to consider that there is a relationship between the earthquake and the vision of the shooting star, even if he does not tell us so explicitly. In the Middle Ages, earthquakes were commonly associated with comets ${ }^{65}$.

(22) Segorbe $\left(\lambda=0^{\circ} 29^{\prime} \mathrm{W}, \varphi=39^{\circ} 51^{\prime} \mathrm{N}\right.$, Valencian Community, Eastern Spain), AD 1496 February 14

A 14 de Febrer dit any vexen sobre Segorb una hora après migjorn una barra de foch puix negant de ample de una na, vegenla la bolta de Llevant.

On 14 February of this year (1496) (they) saw over Segorb an hour after midday a bar of fire a hand of width, towards Llevant $(E)$.

Next to this little note, in this source from the Llibre De Noticies De La Ciutat De Valencia $^{66}$, the author states that this is "a comet", but it is not, according to his own description. The date, corresponding to a low activity period, makes impossible to attempt an identification. 


\begin{tabular}{|c|c|c|c|c|c|}
\hline $\mathbf{N}^{\mathbf{o}}$ & Julian Date & Place & Event & $\begin{array}{l}\text { Identificati } \\
\text { on }\end{array}$ & $\begin{array}{c}\text { Moon: } \\
\text { Position/Phase }\end{array}$ \\
\hline $1 *$ & AD750 Apr 5 & Spain & $\begin{array}{c}\text { Meteor } \\
\text { Storm }\end{array}$ & Lyrids? & $\begin{array}{c}\text { Aquarius } \\
0.42\end{array}$ \\
\hline 2 & AD839 Apr-May & Spain & $\begin{array}{l}\text { Meteor } \\
\text { Storm }\end{array}$ & $\begin{array}{c}\text { Eta } \\
\text { Aquariids }\end{array}$ & $\begin{array}{c}\text { Sagittarius } \\
0.92 \text { (5 May) }\end{array}$ \\
\hline 3 & AD902 Oct 28 & Spain & $\begin{array}{l}\text { Meteor } \\
\text { Storm }\end{array}$ & Leonids & $\begin{array}{l}\text { Leo } \\
0.31\end{array}$ \\
\hline 4 & AD912/13 & Andalusia & $\begin{array}{l}\text { Meteor } \\
\text { Storm }\end{array}$ & $?$ & $?$ \\
\hline $5 *$ & AD934 Oct 15 & $\begin{array}{l}\text { Córdoba, } \\
\text { San Millán }\end{array}$ & $\begin{array}{l}\text { Meteor } \\
\text { Storm }\end{array}$ & Leonids & $\begin{array}{c}\text { Sagittarius } \\
0.18 \\
\end{array}$ \\
\hline 6 & AD935 Oct 13 & Córdoba & $\begin{array}{c}\text { Meteor } \\
\text { Storm }\end{array}$ & Leonids & $\begin{array}{c}\text { Piscis } \\
0.98\end{array}$ \\
\hline $7 *$ & AD 939 Jun 1 & $\begin{array}{c}\text { Several } \\
\text { Cities }\end{array}$ & Bolide & --- & $\begin{array}{c}\text { Libra } \\
0.90\end{array}$ \\
\hline 8 & AD973 Jun 25 & Cordoba & Meteor & --- & $\begin{array}{c}\text { Pisces } \\
0.58\end{array}$ \\
\hline $9 *$ & $\begin{array}{l}\text { End Xth-Beg XIth } \\
\text { century }\end{array}$ & Cordoba & Meteorite & --- & $\begin{array}{ll}-- \\
\end{array}$ \\
\hline $10 *$ & AD1189 Feb 24 & Tortosa & $\begin{array}{l}\text { Meteor } \\
\text { Storm }\end{array}$ & $\begin{array}{c}\text { Eta } \\
\text { Virginis? }\end{array}$ & $\begin{array}{c}\text { Taurus } \\
0.44\end{array}$ \\
\hline $11 *$ & AD1247 Jan 7 & Serrateix & Bolide & -- & $\begin{array}{l}\text { Sagittarius } \\
0.01\end{array}$ \\
\hline $12 *$ & AD1254 mid Oct & $\begin{array}{l}\text { Castrillo } \\
\text { del Val }\end{array}$ & Bolide & --- & $\begin{array}{c}\text { Saggittarius } \\
0.28\end{array}$ \\
\hline $13 *$ & AD1300 & Aragón & Meteorite & --- & --- \\
\hline 14 & AD1348 Dec 18 & Catalonia & Meteorite & & \\
\hline $15 *$ & AD1410 Sep 2 & Antequera & Meteor & --- & $\begin{array}{c}\text { Aries } \\
0.90 \\
\end{array}$ \\
\hline $16^{*}$ & AD1433 Jan 5 & $\begin{array}{l}\text { Ciudad } \\
\text { Rodrigo }\end{array}$ & Bolide & $\begin{array}{l}\text { Daytime } \\
\text { Arietids? }\end{array}$ & $\begin{array}{c}\text { Geminis } \\
0.99\end{array}$ \\
\hline $17 *$ & AD1451 Aug 22 & Bayona & Meteorite & --- & $\begin{array}{c}\text { Geminis } \\
0.22\end{array}$ \\
\hline $18^{*}$ & AD1459 May? & Castille & Meteor & --- & $\begin{array}{c}\text { Libra } \\
0.95 \text { (15 May) }\end{array}$ \\
\hline $19 *$ & AD1459 Oct 28 & Barcelona & $\begin{array}{l}\text { Meteor } \\
\text { Storm? }\end{array}$ & Leonids? & $\begin{array}{l}\text { Ophiuchus } \\
0.04\end{array}$ \\
\hline $20 *$ & AD1464 Oct 10 & Barcelona & Meteor & Draconids & $\begin{array}{c}\text { Aquarius } \\
0.76\end{array}$ \\
\hline $21 *$ & AD1471 Dec 18 & Barcelona & Meteor & Geminids & $\begin{array}{c}\text { Pisces } \\
0.40\end{array}$ \\
\hline $22 *$ & AD1496 Feb 14 & Segorbe & Meteor & Meteor & $\begin{array}{c}\text { Aquarius } \\
0.00\end{array}$ \\
\hline
\end{tabular}

Table 2: Meteoritic events listed in the paper. A (*) next to the number means that this account has not been previously published, with the exception of records 19, 20 and 21, which have been previously commented $^{67}$ 


\section{DUBIOUS RECORDS}

(1) Mérida $\left(\lambda=6^{\circ} 20^{\prime} \mathrm{W}, \varphi=38^{\circ} 54^{\prime} \mathrm{N}\right.$, Extremadura), AD 560-571

(...) y montando en su caballo, llegó antes de la media noche á la puerta de la Ciudad, llamada puerta del Puente, la qual estaba cerrada y como nadie le respondiese, puso el Caballo á pacer mientras abriesen. Vio entonces un globo de fuego, que salía dé la Iglesia de San Fausto (distante de la Ciudad una milla), y llegó hasta la de Santa Lucrecia, y al punto vio una, multitud de Santos (entre los que estaba. Fidel), que siguiendo el globo de fuego por el puente, llegaron á la puerta.

(...) And riding his horse [he] arrived before midnight at the door of the city called puerta del Puente, which was locked and nobody answered him, so he put the horse to graze while [he waited the door to] open. He then saw a ball of fire coming out of the church of San Fausto (distant one mile of the city), and reached the church of Santa Lucrecia. He waited to see what happened and immediately saw a multitude of saints (including Fidel), which following the ball of fire on the bridge arrived to the door (...)

This is an exception in the aim of the paper, because we intended to include only meteorite reports from the VIII to the XV century, but we found this report while we were searching the source ESP SAG 13, p. 177 and we found it interesting enough to be included in the survey all the same.

If we do not consider the end of the paragraph, this entry clearly corresponds to the view of a meteor. The fragment belongs to the life and miracles of Saint Fidel, who was Bishop Merida of from AD560 to AD571. In particular, the paragraph narrates the vision that one of the Saint's family members had. The original story comes from Paulus Emeriteanus Diaconus ${ }^{68}$. We consider that this paragraph narrates a miracle maybe based on a real vision of a meteor. The current localization of the churches has been lost, but S. Fausto church could have been in the top or hill that is among the roads out of Merida and go to Calamonte and Arroyo. The other church (Santa Lucrecia ) is surely Ntra. Señora del Loreto ${ }^{69}$.

(2) Ripoll $\left(\lambda=2^{\circ} 11^{\prime} \mathrm{E}, \varphi=41^{\circ} 12^{\prime} \mathrm{N}\right.$, Northern Catalonia), AD 785

Anno DCCLXXXV. (...) multi viderunt sanguine pluere, et mortalitas magna secuta est. Apparuerunt acies in coelo et signum + in vestimentum hominess.

Year 785. (...) Many saw blood raining, and it was great mortality. It appeared signals on the sky and crosses on the men's clothes.

Reported in the Annals De Ripoll $I^{70}$, the original input comes from the Annals of Moissac (MGH SS 1), mixing two accounts ${ }^{71}$. One of them states that in December 
786 there were signs in the sky .The Chronica aevi Suevici (MGH SS 23) p.2 is more accurate when it states that this event happened in 785 and there were acies (lines?) on the sky. The question is not if something was seen, but if it was a shower of stars, northern lights and if, indeed, it was really seen in Ripoll or it is only a copy of the manuscript of Moissac, which is sited further north.

It is tempting to relate this account to the meteor storm seen in Japan on AD784 December $24^{72}$, but there is no sufficient evidence to make such affirmation.

(3) Navarre (North-Eastern Spain), AD 840

Las turbaciones de la Francia contra Carolo Calvo, que el sancto Martyr dize en su carta, hallo por la parte de Cataluña, y Narbonesa, y por la parte de Aquitania, que confina con Navarra, que comenzaron a fraguarse al principio del año 840 y parece se fueron encendiendo don la llama del Cometa muy ardiente y de grande amenaza que se vió à primero de Enero de aquel año, en el signo de Scorpion, à que siguio pocos dias despues la muerte de Pipino, que posseia como Rey yà à Aquitania.

The troubles in France against Charles the Bald, that the holy Martyr said in his letter that he found in Catalonia and Narbonne, and the part of Aquitaine bordering with Navarre began to take shape at the beginning of the year 840, and it seems that they went on with the very hot flame of the threatening comet, which was saw the first of January of that year, in the sign of Scorpio, which was followed a few days after by the death of Pippin, who already possessed Aquitaine as king.

From the Annales Del Reyno De Navarra ${ }^{73}$. Two comets are reported for the year AD840, in March and in December ${ }^{74}$. However, this report mistakes the date, because Pippin died in December 838 and the very hot flame was seen a few days before the death of Pippin (his successor was Charles the Bald (823-877)) so it surely refers to $\mathrm{X} / 838 \mathrm{~V} 1$, that was first observed in China.

(4) Pueyo de Araguás $\left(\lambda=0^{\circ} 9^{\prime} \mathrm{E}, \varphi=42^{\circ} 26^{\prime} \mathrm{N}\right.$ Aragón, Eastern Spain), IX Century

Acaeciole un dia estando para pelear con los Moros, que se vio cercado de gran multitud dellos, y como sus entes estuuiessen por desmayar, alço los ojos al cielo pidiendo socorro a Dios y su madre bendita, y vio el señal de la cruz muy resplandeciente a su parte derecha en el cielo sereno, y como le viessen con el todos los otros que alli eran, tomaron tan denodado esfuerzo que con el ayuda de Dios vencieron la batalla y hizieron grandissima matança entre los Moros.

It happened one day during a fight against the Moors, that [he] found surrounded by a large crowd of them, and as his people were to loose heart, 
he raised his eyes to heaven praising for the help of God and his blessed mother, and saw the sign of a very shining cross on his right in the clear sky, and as they all saw [this sign], they strengthen their efforts so that, with the help of God, they won the battle and did a very great slaughter among the Moors.

This text from the Primera parte de la Coronica general de toda España y especialmente del reyno de Valencia ${ }^{75}$ accounts a vision of Iñigo Arista (770-851), first King of Navarre, and his army. It is a vision that recalls the one of Constantine before the battle of Milvian Bridge. Other local sources relate this same event to a battle near the village of Ainsa in AD724. In this case, the so called King of Sobrarbe (one of the counties of Aragon) was García Jiménez (VIIIth century) and the sign was a burning cross on an oak. In any case, Iñigo Arista's cross became the personal symbol of Kings of Aragon from Ramiro I (1035-1063).

(5) Hacinas ( $\lambda=3^{\circ} 17^{\prime} \mathrm{W}, \varphi=41^{\circ} 59^{\prime} \mathrm{N}$, Castille), Xth century, AD 939?

The following report is registered in several sources, such as the Poema de Fernán González $^{76}$ and the Primera Crónica General ${ }^{77}$ in both cases a sierpe (snake) was seen; and also in the Crónica geral de Espanha de $1344^{78}$ where a dragon appeared in the sky.

The three texts differ only in little details. For example, in the Poema de Fernán González the reddish color of the snake is remarked. We reproduce the fragment from the Crónica geral de Espanha de $1344^{79}$ :

E, el em esto estando, cada hüu em seu logar, virom essa noyte vĩir voando pello aar hũu dragõ muy grande e muy spantoso, dando muy grandes braados: $e$ semelhava que viinha todo cheo de sangue (...) E levava a boca aberta e lançava per ellas chamas de fogo, que semelhava que toda a hoste queria queymar (...)E nõ ouve hy nẽ hũu, por esforçado que fosse, que esto visse, que dello nõ ouvesse muy grande spanto, cuydando que querya decender sobre elles (...). E a esto forõ despertar o conde que jazia dormyndo. E, quando o code foy esperto era ja o dragõ espedido.

That night, they saw coming flying through the sky a very large and very frightening dragon, with loud cries; and it seemed that it came covered of blood (... ) And it had its mouth open and threw though it flames of fire, so that it seemed that it wanted to burn the whole army (...) And there was no one watching this that did not panic [because they] believed that it wanted to descend upon them (...) and they went to wake the Count, who lay asleep. And when the count awoke the dragon was gone.

This narration is the description of an event that happened the day before the battle of Hacinas (supposedly in AD939) between the Castilian Count Ferran Gonzalez (910970) and 'Abd al-Rahmân III (912-961, al-manșūr (939-1002) in some of the texts in what it seems to be an anachronism). Historians quite agree that this battle never 
happened, but it is very tempting to think that the narrator is, in fact, telling the passage of a very bright meteor that he actually witnessed. The use of the word snake and dragon corresponds to the medieval mention of a meteor, according to Dall'Olmo ${ }^{80}$.

\section{(6) Navarre, AD 1000 January 1}

A la verdad, el año fue dentro y fuera de España, memorable generalmente, por el error vulgar, que nacido en Francia, cundió como gentagio por todo el orbe, de que era el año final del mundo, y que el el se habia de acabar. A que aiudò la estrañeza de los prodigios porque fuera de un gran terremoto, el primer dia del año apareció un cometa: y rasgandose al parecer el cielo, corriò por largo trecho sobre la tierra una gran llama, à modo de relampago de grandissima viveza, que tocò a muchos en los campos, y en sus casas: y bolviendo à consolidarse aquella como rotura del cielo, apareciò en el aire una espantosa figura, que fue creciendo con cabeza como de serpiente, y pies azules.

And truly the year was, within and outside Spain, memorable, because of the common error, which was originated in France that spreaded like contagion throughout the world that [in this year] was the end of the world, which was to be finish. This [assumption] was supported by the unusual wonders [that appeared]: because apart from a great earthquake, the first day of the year appeared a comet: and apparently tearing the sky, ran long way on earth a great flame, like a very intense lighting which touched many fields, and houses: and [then] consolidating the break in the sky, appeared in the air a frightening figure, which grew with snakelike head, and blue feet.

The text from the Annales del Reyno de Navarra ${ }^{81}$ refers to a comet, but the fact that it was seen the first day of the year 1000 and that the author seems to refer to a quickmoving object, makes us think that what we find here is the description of a bright meteor or a bolide seen somewhere in Navarre.

The author relates also the year 1000 to the end of the world, stating that this fear came from France. He surely refers to the chronicles of Raoul Gabler ${ }^{82}$ who recorded several omens and prodigious events that happened around this year, among them a comet and several solar and lunar eclipses.

However, our concern about this entry does not come from the fact that maybe is reflecting some kind of fear to the 1000 year, but from the fact that we have found other records that describe similar facts with almost exactly the same words in different places and years. For example, in the Anales Dorenses (MGH SS 27) p. 519:

Anno Iesu Christi millesimo secundum supputationem Dionisii multa prodigia visa sunt. Terremotus factus est permaximus. Cometes apparuit 19. Kal. Ianuarii circa horam nonam fisso cello quasi facula ardens cum longo tractu; instar fulguris illabitur terries tanto splendore, ut non modo qui in agris errant, sed 
etiam in tectis irrupt lumine ferirentur. Qua celi fissure sensim evanescente, interim visa est figura quasi serpentis capite quidem crescent cum ceruleis pedibus.

Year $1002 A D$ according to the computes of Dionysius a lot of prodigious events are seen. Big earthquakes. A comet appeared on December 14, about three [and] divided the sky burning like a torch a long way; like a lighting that was seen not only by those who were in the fields, but also by those who were in their homes. While the crack was vanishing, a figure was seen with snakelike head, and blue feet

We find a similar description (especially regarding to the snakelike head and the blue feet), also on 14 December, for the year AD1002 in the Gesta Episcoporum Cameracensium (MGH SS, 7) and in other European sources. So, in our opinion, there was a meteor, but the assumption from the Annales Del Reyno De Navarra that this meteor was seen the first day of the year 1000 is questionable, and more related to the aim of the author of highlighting this year. Possibly all these registers are copies from each other.

(7) Cervera $\left(\lambda=1^{\circ} 16^{\prime} \mathrm{N}, \varphi=41^{\circ} 40^{\prime} \mathrm{E}\right.$, Catalonia), AD 1176

Era $M^{a} C C X I I I I$, anno $M^{\circ} C L X X V I$. Multi viderunt sanguinem pluere in termino Cervarie et in aliis locis.

Era 1214, AD 1176, many people saw blood raining in the boundary of Cervarie and in other places.

Report from the Annals De Tortosa $I^{83}$. Cervarie corresponds to the current Catalan city of Cervera. In this case, we are not sure what kind of event had the author in mind. Although rare, the so called blood rain is not impossible and, in fact, it has been recorded several times in different places, usually covering small areas. It is more common in southern Europe: Spain and the South of France, which are closer to the Sahara. Before the 17th century, explanations for the phenomenon were always superstitious, but already in the 19th century appeared theories that dust gave the water its red color. Today, this is the dominant theory, together with the presence of micro-organisms, however alternative explanations include aurorae (difficult in this latitude, but not impossible) and meteor storm.

(8) Xativa ( $\lambda=0^{\circ} 31^{\prime} \mathrm{W}, \varphi=38^{\circ} 59^{\prime} \mathrm{N}$, Valencian Community), AD1242 May 2829

Este año en la noche de la Ascension de nuestro Señor viò el Rey una imensa luz que baxava del Cielo, y llenaba la redondez de la tierra, y admirado dixo à los suyos: sin duda que Dios obra algo grande esta noche, y fue la del Martyrio de Guillermo Arnaldo de Mompeller Inquisidor. 
This year, on the night of the Ascension of our Lord, the King saw an immense light coming down from heaven, and filled the roundness of the earth, and (he was) admired (and he) told his men: no doubt that God does something great tonight, and it was the (night of) the martyrdom of Guillermo Arnaldo of Mompellier (...)

Obtained from the Anales De Cataluña Y Epílogo Breve ${ }^{84}$, the author refers to an earlier work : Los reyes de Aragón en los anales históricos ${ }^{85}$, which places the event in Xativa.

This narration is consistent with in the sense that the king Jaime I (1208-1276) was effectively besieging Xativa, from May 28 to 29. Indeed, it is not impossible that the event really happened, but the chronicle narrated by King Jaime I himself (Llibre dels $F_{e y t s}{ }^{86}$ ) says nothing about this and it seems difficult to believe that the king did not include such an important signal. It looks more likely that the author has wanted to give a supernatural aura to a fact that really happened that night (actually, the Ascension of our Lord) concerning Guillaume Arnaud, papal inquisitor, who was killed in Avignonet with, among others, Etienne de Saint- Thibéry, and whose death caused great outrage.

(9) Roa ( $\lambda=3^{\circ} 55^{\prime} \mathrm{W}, \varphi=41^{\circ} 41^{\prime} \mathrm{N}$, Near Burgos), January AD1438

We find this event in the Crónica De D. Juan $I I^{87}$ but the narration of a witness in the Centón epistolario ${ }^{88}$ is much more detailed:

Estando el Rey é todos los de la Corte cazando al pie de la cuesta desta Villa de Roa, desque el sol se metió en unas nubes blancas, se veían baxar unos cuerpos á manera de peñas pardas é mas oscuras , é tanto espesas é grandes, que todos ovieron gran maravilla. E después de colar una hora paró todo, é el sol se tornó á descobrir, é fueron unos buitreros en sus rocines á dó cayera aquella cosa, que á media legua escasa sería ; é volvieron á decir, que todo el campo cubierto era de peñas grandes é chicas, que la dehesa no se veía. (...) é traxo quatro de aquellas peñas, é yo era presente á ello , que al verlas caer non fui presente (...) son algunas como morteros redondos, é otras como medias almoadas de lecho éé otras como medidas de medias fanegas, tanto leves é sotües de levantar, que las mas grandes media libra no pesan, é tan moles é blandas, que á las espumas del mar espesadas semejan, ca si dan á uno en la mano no le facen ferida, ni dolor, ni señal.

While the king and all the court were hunting at the foot of the slope of the village of Roa, when the Sun got into a white clouds, you could see some bodies as brown and darker rocks falling down, and [they were] so thick and large that they all marveled. And after an hour everything stopped, and the sun was exposed again, and some buitreros ${ }^{89}$ rode their nags where the thing fell, it would be about half a league apart; and they returned to say that the whole field was covered with large and small rocks, the pastureland could not be seen (...) and they brought four of those rocks, and I was present, (because when) they fell I was not present (...) some of them are like round mortars, others like half pillow bed, and others as half fanega ${ }^{90}$, [they are] so slight and subtle to lift that 
the bigger ones do not weigh half a pound, and as big and soft that they resemble thickened sea sponges, so that if they hit someone in the hand they do not make any wound, nor pain, nor signal (...)

No remains of this possible meteorite have been preserved up to our time. In our opinion, it was a meteorological phenomenon. The description seems to fit with a rain of pumice stone. Anyway, the writer states that a lot of people gave political significance to this event, considering it a bad omen.

\section{CONCLUSIONS:}

We have reported several previously non published sources of meteoritic events included in several local Spanish sources. We provide a survey of 31 certain and dubious records, 25 of them previously unnoticed. These accounts will be useful to provide a more complete list of meteor events in Europe with the final aim to carry out a research about the evolution in time of the main meteor storms.

Regarding the reports themselves, most of them are simple descriptions of natural phenomena for example (2), (11), (12), (14), (15), (22) and they do not try to search any explanation nor give a signification to these facts. The different authors do not seem to clearly link celestial phenomena with, for example, meteorological phenomena or earthquakes, with the exception of (19), (20) and (21) and even in this case the relationship is not explicit. In some cases, the celestial phenomena are reinforcements for some war action (17), an omen (1), (5), (18), (19) or the expression of the Heaven's approval (17).

\section{ACKNOWLEDGEMENTS:}

Part of this work was supported by grant P1.1B2012-47 from Universitat Jaume I. The authors wish to thank the Servei de traducció de la Universitat Jaume I de Castello for their help in translating some of the ancient expressions contained in the documents.

\section{NOTES ON CONTRIBUTORS}

MARÍA JOSÉ MARTÍNEZ USÓ is a researcher in the Applied Mathematics Department of the Universidad Politécnica de Valencia, Spain. She worked in celestial mechanics for some years before obtaining a degree in history. Since 2008 she has combined fundamental astronomy and history of astronomy, with a focus on astronomical records in medieval documents from the Iberian Peninsula.

FRANCISCO J. MARCO CASTILLO is a researcher in the Mathematics Department at the Universidad Jaime I de Castellón, Spain. He worked in celestial mechanics for some years and then became interested in history of astronomy. Since 2008 he has combined fundamental astronomy and history of astronomy. His current topic of research is the study of astronomical reference frames and the application of ancient astronomical records in order to obtain valuable results in fundamental astronomy. 


\section{REFERENCES}

\section{ABREVIATED TITLES OF COLECTIONS CITED ABOVE}

MGH, SS: Monumenta Germaniae historica, Scriptores (32 vols, Hannoverae etc., 18261876)

RIS: Rerum Italicarum Scriptores.(3 Series, Muratori etc. 1723-2012)

ESP SAG: España Sagrada. Teatro geográfico histórico de la Iglesia de España. (51 Volumes, Flores etc. Madrid. 1747-1957)

1. Dall'Olmo U. "Latin terminology relating to aurorae, comets, meteors and novae" Journal for the History of Astronomy. 9. (1980) 10-27

2. Newton H.A. American Journal of Science and Arts. (Series 2),36, (1863) 145-149. And also: Newton H.A. "The Original accounts of the displays in former times of the November starshowers; together with a determination of the length of its cycle, its annual period, and the probable orbit of the group of bodies around the Sun" American Journal of Science and Arts. (Series 2),37, (1864), 377-389.

3. Dall'Olmo U. Meteors, "Meteor showers and Meteorites in the middle ages: from European Medieval sources" Journal for the History of Astronomy. ix, (1978),123-134

4. Rada W.S., Stephenson F.R. "A catalogue of Meteor showers in Medieval Arab chronicles". Q. J. R. astron. Soc. 33. (1992) 5-16.

5. Kidger M.R. "Some comments on the identification of Medieval Meteor showers recorded by the Arabs". Q. J. R. astron. Soc. 34. (1993) 331-334.

6. Cook D. "A survey of Muslim material on comets and meteors". Journal for the History of Astronomy. 30. (1999) 131-160.

7. Noteworthly in this regard the work of Vernet Ginés J. "Algunos fenómenos astronómicos observados bajo los Omeyas españoles". Revista del Instituto Egipcio de Estudios Islamicos. 21. (1981) 23-20 and also the older paper of Codera F. "Datos acerca de cometas en dos historiadores árabes". Boletín de la real academia de la historia. 56. (1910). 364-370.

8. Imoto, S. \& Hasegawa, I. "Historical Records of Meteor Showers in China, Korea, and Japan”. Smithsonian Contribution to Astrophysics, Vol. 2, (1958) 131-144

9. See Martín Escorza C. "Fenómenos meteoríticos ocurridos en España". Boletín de la institución Libre de Enseñanza. 3. (1987) 51-68 and also Paluzie Borrell A. "Meteoritos Españoles". Urania. 225. (1959) 25-48.

10. See, for exemple, http://www.solosequenosenada.com/meteorito/index2.php

11. http://www.iec.cat/iecavui/carolingia.html

12. About this issue see, for example, Ortega Cervigón J.I. "La Medida Del Tiempo En La Edad Media. El Ejemplo De Las Crónicas Cristianas". Medievalismo, 9, (1999) 9-39

13. Sang-Hyeon Ahn. "Meteors and showers a millenium ago". Mon. Not. R. Astron. Soc. 343. (2003). 1095-1100. And Sang-Hyeon Ahn. "Meteoric activities during the $11^{\text {th }}$ century". Mon. Not. R. Astron. Soc. 358. (2005). 1105-1113.

14. López Pereira, José Eduardo, Crónica mozárabe de 754 (Zaragoza: Anubar, Textos medievales 58, 1980).

15. Vasaeus, J. Chronici rerum memorabilium Hispaniae: Tomus prior, autore Ioanne Vaseao (Salmanticae : excudebat Ioannes Iunta. 1552) 119r

16. Ibid. p $119 \mathrm{v}$.

17. Jiménez de Rada, R. Crónica de España por el Arzobispo de Toledo Don Rodrigo Jiménez de Rada, traducida al castellano y continuada por Don Gonzalo de la Hinojosa, Obispo de Burgos, y después por un anónimo hasta 1430. In Doumentos Inéditos Para la Historia de España T.CV by El Marqués de La Fuensanta del Valle.(Madrid, 1893). 247 
18. Ibn al-Athir, trans. E. Fagnan. Annales du Maghreb et de l'Espagne, (Paris: Imprimerie Orientale Pierre Fontana. 1904). T.2, 139.

19. Op cit. $(\operatorname{Ref} 6)$.

20. Op cit. $(\operatorname{Ref} 4)$.

21. Op cit. $(\operatorname{Ref} 7)$.

22. Op cit. $(\operatorname{Ref} 3)$.

23. Jenniskens P. Meteor showers and their parent comets. (Cambridge: Cambridge University Press, 2006)

24. Astapovic I.S., Terenteva A.K. "Fireball radiants of the $11-15^{\text {th }}$ centuries", in Physics and dynamics of meteors. IAU Symp 33. (1968). 308-319

25. Newton H.A. "The original displays in former times of the November star-shower". The American Journal of Science and Arts. $2^{\text {nd }}$ Series. 37. (1864). 377-389.

26. Ibn al-Athir, trans. E. Fagnan. Annales du Maghreb et de l'Espagne, (Paris: Imprimerie Orientale Pierre Fontana, 1901). T.1, 178.

27. Op cit. (Ref 24$)$.

28. Op cit. $(\operatorname{Ref} 4)$.

29. Op cit. $(\operatorname{Ref} 22)$.

30. See Newton Op cit. (Ref 24) and Hughes D. "The History of Meteors and Meteor Showers". Vistas in Astronomy. 26. (1982). 325-345.

31. Op cit. (Ref 4).

32. An explanation of the manuscript (only the first two books have been translated) may be found in http://cosmos.bodley.ox.ac.uk/content.php/boc?expand=732, while the text translated into English may be found in Savage-Smith E. and Rapoport Y. (eds.) The Book of Curiosities: A critical edition. (2007) WWW publication. (www.bodley.ox.ac.uk/bookofcuriosities)

33. Op cit. (Ref 7).

34. Lancaster Brown, P. In Comets, meteorites and men, (London: Robert Hale and Co. 1973).

35. Op cit. (Ref 5). p 204

36. Mariana, J. Historia General de España. (Madrid, edited by J. Martínez Romeo. 1780). Tome I, 420

37. Op cit. (Ref 4). The Muqtabis is considered one of the most important sources for the study of Muslim Spain. It was written by Ibn-Hayyān (Cordoba 987-1076). It is a collection in which the author borrows passages from various authors. There were originally of 10 volumes, the second ( between 180 / 796-267 / 881 ), third ( 275 / 888-299 / 912) and fifth ( 299 / 912-330 / 942 ) remain virtually intact while the seventh (360/971-364/975) has been only partially preserved .

38. Op cit. $(\operatorname{Ref} 4)$.

39. Op cit. (Ref 5).

40. 'Isa Ibn Ahmad Al-Razi. Anales Palatinos del califa de Córdoba Al-Hakam II, por 'Isa Ibn Ahmad Al-Razi. Trad. Emilio García Gómez. Sociedad de Estudios y Publicaciones. (Madrid. 1967)

41. Op cit. (Ref 6).

42. Ibn Rushd, Aristotelis de Coelo, de generatione, \& corruptione, meteorologicum, de plantis libri, cum Averrois Cordubensis variis in eosdem commentariis: editio Juntina prima, vol. V (Venezia, 1550) 441

43. Op cit. ( Ref 8$)$.

44. Cingolani, S.M. Els Annals de la Família Rivipullense $i$ les Genealogies de PallarsRibagorça. (Valencia: Universitat de valència. 2012). 137

45. Masnou i Pratdesaba J.M. "Els Necrológics de Serrateix". Miscel.lania litúrgica catalana XXI. (2013). 115-150.

46. A "glera" is a cobble area. In particular, the Glera of Burgos refers to a sandy area next to the Arlanzón river, where traditions says that Rodrigo Díaz de Vivar, "El Cid" (1048-1099) camped for the first time after being exiled by King Alfonso VI of Castile.

47. Op cit. ( $\operatorname{Ref} 8)$.

48. Jimeno H. "Noticias Históricas sobre algunas piedras meteoríticas caídas en España". Bol. Soc. Esp. Hist. Nat. 29. (1901). 101.

49. See, for example, Bofarrul Brocà, A. Crónica del rey de Aragón, don Pedro IV el Ceremonioso o del Punyalet, escrita en lemosin por el mismo monarca. Traducida al castellano y anotadas por Antonio Bofarrull Brocà, (Barcelona, 1850)

50. Op cit. (Ref 3). 
51. Pérez de Guzman, F. Crónica de Juan II de Castilla. (Sevilla : En casa de Andres de Burgos : A costa y mission de Pedro ximenez y Diego ximenez mercaderes de libros, 1543). 40v

52. Designated representative in the courts by the cities and towns.

53. Op cit. (Ref 50). p. 159r

54. Gómez de Ciudad Real, F. Centón epistolario del bachiller Fernán Gómez de Cibda Real. (Burgos. 1499). 130-135

55. Op cit. (Ref 35). T. 3. p. 22

56. Moret, J. Annales del Reyno de Navarra. (Pamplona, 1684). T.3. p. 450

57. Op cit. (Ref 35). Tome 3. p 111

58. Sans i Travé J.M.(Dir.) Dietaris de la Generalitat de Catalunya. (Barcelona: Generalitat de Catalunya, 1994). Vol. 1. 151

59. Sans i Travé J.M (ed). Dietari o Llibre de les Jornades de Jaume Safont (1411-1484) (Barcelona, 1992). 64r

60. Martínez M.J., Marco F.J. "New Astronomical References in Two Catalonian Late Medieval Documents". Early Science and Medicine. 14. (2014) 175-185.

61. Kronk G.W. Cometography. Vol I. A catalog of comets. (Cambridge: Cambridge University Press, 1999)

62. Op cit. (Ref 57). Vol. 1. p. 183

63. Pedro de Coimbra (c.1429 -1466) In 1463, the Catalan institutions, which were in civil war with Juan II of Aragon, offered the crown of Aragon to Pedro. He was proclaimed King of Aragon, Count of Barcelona, and King of Valencia by the Consell de Cent, but the territory under his control only included Barcelona, Catalonia and parts of Aragon.

64. Op cit. (Ref 57). Vol. 1. p. 206

65. See, for example, Oeser, B. "Historical Earthquake Theories From Aristotle To Kant”.. Abh. Geol. B.-A. Volume I. (1992) 11-31.

66. Cavaller, F.J. Dietario de Guillem Mir + Llibre de noticies de la ciutat de Valencia desde el any 1306 al de 1535. (Valencia) 1535. 128v (Manuscript digitalized at http://roderic.uv.es/handle/10550/37208)

67. Op cit. (Ref 59).

68. Paulus Emeritiensus Diaconus. De vita Patron Eneritensium. 134 (Manuscript digitalized at http://www.documentacatholicaomnia.eu/02m/06100610,_Paulus_Emeritanus_Diaconus,_De_Vita_Patrum_Emeritensium,_MLT.pdf)

69. Moreno de Vargas B. Historia de la ciudad de Mérida. (Mérida:Ed. Maxtor, 2005). First edited in 1892.

70. Op cit. (Ref 43$)$. p. 38

71. According to Cingolani, Op cit. (Ref 43). p. 38

72. Op cit. (Ref 7).

73. Op cit. (Ref 55). p. 234

74. Op cit. (Ref 60)

75. Beuter, P.A. Primera parte de la Coronica general de toda España y especialmente del reyno de Valencia. (Valencia. 1554). Book II. 28

76. Menéndez Pidal R. Reliquias de la poesía épica española, (Madrid: M. Rivadeneyra. 1951)

77. Menéndez Pidal, R. Primera crónica general: estoria de España que mandó componer Alfonso el Sabio y se continuaba bajo Sancho IV en 1289, (Madrid: Bailly-Bailliére. 1906)

78. Cintra, L. F. L. 1951. Crónica geral de Espanha de 1344 / ed. crítica do texto português por Luís Filipe Lindley Cintra ; [ed.] Academia Portuguesa da História. Lisboa : A.P.H., (Fontes narrativas da história portuguesa ; 2)

79. Ibid. p. 50

80. Op cit. (Ref 1$)$.

81. Op cit. (Ref 51). Book XII . p. 512

82. Rodolfo il Glabro. Storie dell'anno Mille: I cinque libri delle Storie e Vita dell'abate Guglielmo, a cura di Giancarlo Andenna, Dorino Tuniz, (Milano: Jaca Book. 2004)

83. Op cit. (Ref 43) p. 137

84. Feliu de la Peña y Farell, N. Anales de Cataluña y Epilogo Breve de los Progressos, y Famosos Hechos de la Nación. (Barcelona. 1709). T. 2. 50.

85. Abarca, P. Los Reyes de Aragón en anales históricos. (Madrid. 1682). 270v

86. A. Ferrando, V.J. Escarti. Llibre dels Fets (Ed. Afers, Barcelona. 1995)

87. Op cit. (Ref 50).

88. Op cit. (Ref 53).

89. Vulture Hunters 
90. The fanega was an old measure generally used in an agricultural context to measure quantities of grain. In Castile, it was roughly equivalent to 55.5 liters. 